\title{
Peningkatan Kapasitas Working Memory melalui Permainan Congklak pada Siswa Sekolah Dasar
}

\author{
Andy Surya Putra ${ }^{1}$, Sri Tiatri ${ }^{2}$, E Naomi Soetikno \\ 1,2,3Fakultas Psikologi Universitas Tarumanagara
}

\begin{abstract}
Working memory capacity is a limited cognitive complex ability required for holding and manipulating information in a brief period for learning, thinking, giving attention, counting, memorizing, comprehending and problem solving. Congklak traditional game involves cognitive complex abilities, giving attention, counting, reasoning and planning. The aim of this research was to predict the impact of playing congklak game to the working memory capacity. The subject of this research consisted of 12 elementary students from grade $\mathrm{V}$ that were divided in two groups of experimental designed. Analysis of the data using independent sample T-test of experimental and controlled group showed digit span $(p<.05)$, square span reverse $(p<.05)$, square span forward ( $p>05)$ and mean score of academic achievement in the class $(p>.05)$. The result showed that there was a significant impact of congklak game to working memory capacity in visual imagery and verbal.
\end{abstract}

Keywords: academic achievement; congklak; phonological loop; visuospatial sketchpad; working memory capacity

Abstrak. Kapasitas working memory adalah sebuah kemampuan kognitif kompleks terbatas dalam menyimpan sementara dan memanipulasi informasi untuk belajar, berpikir, memberi perhatian, berhitung, mengingat, memaknai bacaan, dan memecahkan masalah. Permainan tradisional congklak melibatkan kemampuan kognitif kompleks, berhitung, memberi perhatian, bernalar, dan berstrategi. Tujuan dari penelitian ini adalah untuk menguji adanya pengaruh permainan congklak terhadap kapasitas working memory pada siswa. Subjek penelitian adalah 12 siswa kelas V Sekolah Dasar yang dibagi menjadi dua kelompok dengan metode eksperimen. Analisis data dengan independent sample T-test antara kelompok kontrol dan kelompok perlakuan menunjukkan digit span $(p<0,05)$, square span reverse $(p<0,05)$, square span forward $(p>0,05)$ dan nilai rerata pelajaran kelas $(p>0,05)$. Hasil penelitian menunjukkan permainan congklak dapat meningkatkan kapasitas working memory dalam informasi gambar-visual dan verbal.

Kata kunci: congklak; kapasitas working memory; nilai rerata pelajaran kelas; visuospatial sketchpad; phonological loop

Aktivitas pembelajaran, realisasi kemampuan dan prestasi belajar anak usia Sekolah Dasar memainkan peranan

${ }^{1}$ Korespondensi mengenai isi artikel ini dapat dilakukan melalui: andysputra83@gmail.com; ${ }^{2}$ sri.tiatri@untar.ac.id; ${ }^{3}$ naomis@fpsi.untar.ac.id penting dalam perkembangan aktivitas kognitif kompleks individu di masa selanjutnya (Friend, 2011; Santrock, 2011). Realisasi kemampuan dan prestasi belajar anak di sekolah dapat dilihat dari penguasaan beberapa mata pelajaran, 
seperti penguasaan materi berbahasa, berhitung, mengingat, dan berpikir kritisanalitis (Schunk \& Zimmerman, 2012).

Namun demikian, anak usia Sekolah Dasar kerap mengalami kesulitan dalam beberapa aspek tersebut. Kesulitan penguasaan materi tersebut dapat dilihat dari kemampuan yang masih rendah dalam pelajaran mengingat. Studi Putri dan Sudianto (2013) memaparkan 45,95\% (17 dari 37 siswa) tidak mencapai standar ketuntasan belajar dalam pelajaran mengingat di salah satu Sekolah Dasar. Kedua, 73\% dari 50 siswa kelas V mengalami kesulitan Matematika dalam menangkap, memahami dan mengingat rumus (Arindiono \& Ramadhani, 2013). Selain itu, IEA (2007) juga menunjukkan bahwa kemampuan membaca dan memahami bacaan siswa SD/MI di Indonesia masih sangat rendah.

Salah satu faktor penyebab kesulitan anak dalam kemampuan mengingat, berhitung dan membaca adalah rendahnya kapasitas mengingat informasi yang bersifat sementara dalam kapasitas working memory (Alloway \& Alloway, 2010). Kapasitas working memory adalah sistem berkapasitas terbatas yang menyimpan dan memanipulasi informasi bersifat sementara serta memainkan peranan sangat penting dalam proses belajar anak usia Sekolah Dasar, seperti berpikir, bernalar, mengingat, dan memecahkan masalah dalam aktivitas berhitung, berbahasa, dan memahami bacaan (Baddeley, 2000; Bailey, Dunlosky, \& Kane, 2008; Santrock, 2011); mengikuti instruksi, berkonsentrasi (focusing) dan menyelesaikan tugas-tugas akademis (Cockcroft, 2015); serta sebuah konstruk kompleks dalam proses penyimpanan bersifat informasi verbal, spasial, dan visual (Baddeley, 2003).
Terdapat empat komponen dalam model multi-komponen (multiplecomponent model) working memory yang pertama kali diperkenalkan oleh Baddeley dan Hitch pada tahun 1974 yang dikutip oleh Baddeley (2003), yaitu central executive, phonological loop, visuospatial sketchpad, dan episodic buffer. Komponen central executive berfungsi sebagai pengendali perhatian (attentional controller) yang secara terbatas melakukan kontrol terhadap atensi dan dua sub-sistem pada sistem penyimpanan. Visuospatial sketchpad berfungsi untuk memasukkan, menahan dan memanipulasi informasi bersifat visual (images) dan spasial. Phonological loop berfungsi untuk memasukkan, menahan, dan memanipulasi informasi yang berbasis bunyi. Sementara itu, episodic buffer berfungsi untuk mengintegrasikan informasi yang diterima dengan ingatan peristiwa episodik dalam ingatan jangka panjang yang telah ada sebelumnya (Baddeley, 2003).

Kapasitas working memory memainkan peranan penting pada optimalisasi proses belajar dan perkembangan kognisi anak serta dapat digunakan untuk memprediksi keberhasilan prestasi belajar anak dalam bidang akademis (Andrews, Hoy, Enticott, Daskalakis, \& Fitzgerald, 2011; Cockcroft, 2015). Anak usia sekolah yang memiliki kapasitas working memory tinggi memiliki kemampuan dan prestasi belajar yang tinggi dalam aktivitas membaca, memaknai bacaan, berhitung, dan mengingat, mampu berkonsentrasi, dan mengikuti instruksi serta prestasi belajar tinggi secara akademis. Sebaliknya, anak yang memiliki kapasitas working memory rendah akan memiliki kapasitas penyimpanan informasi dan kemampuan belajar yang terbatas dalam menangkap, menyimpan, memroses, memanipulasi dan mengolah informasi ke dalam fungsi kognitif 
kompleks berikutnya (Autin \& Croizet, 2012; Baddeley, 2003).

Kapasitas working memory pada anak usia Sekolah Dasar bersifat fluktuatif (Dirk \& Schmiedek, 2016). Alloway dikutip oleh Cockcroft (2015) juga menambahkan bahwa peningkatan pesat pada kapasitas working memory terdapat pada usia 5-13 tahun. Peningkatan kapasitas working memory pada anak usia Sekolah Dasar dapat dilakukan melalui pelatihan kognitif berbentuk permainan (games) yang bersifat menyenangkan dan memunculkan emosi positif (Fahimi, Arjmandnia, \& Fathabadi, 2014; Hughes, 2010) serta pelatihan strategi mengingat (memory strategy training) yang bersifat terus-menerus, adaptif dan ekstensif (Klingberg, 2010; Thompson \& Holmes, 2008).

Pelatihan berbentuk permainan yang bersifat menyenangkan dan memunculkan emosi positif diperkirakan terdapat dalam permainan congklak. Permainan congklak merupakan suatu permainan yang berasal dari Mesir sebelum abad ke-17, dikenal dan berkembang sejak lama di Indonesia serta merupakan permainan lintas usia secara turun-temurun (De Voogt, 2010). Permainan ini dimainkan oleh dua orang pemain secara berhadap-hadapan di atas sebuah papan dengan dua barisan lubang. Jumlah lubang pada papan permainan congklak adalah 14 lubang dengan 2 lubang berukuran lebih besar di kedua belah tepinya sebagai lumbung penyimpanan. Dua belas lubang akan diisi dengan 7 buah kecik berupa biji-bijian, kelereng ataupun kerang, kecuali kedua lumbung penyimpanan yang terletak di bagian tepi papan. Tujuan dari permainan congklak ini adalah mendistribusikan kecik berlawanan arah jarum jam hingga akhirnya kecik di dalam keseluruhan lubang habis dan pemain yang dapat mengumpulkan paling banyak kecik di dalam lumbung penyimpanannya akan keluar sebagai pemenang.

Dengan bermain congklak, anak dapat meningkatkan kemampuan memberi dan memindahkan atensi, berpikir, berhitung, membuat perencanaan dengan strategi kompleks untuk memenangkan permainan, serta mengambil keputusan untuk memecahkan masalah melalui proses bermain yang menyenangkan (Goldstein, 2012; Muslimin, Putri, \& Somakim, 2012). Peningkatan kapasitas working memory akan berperan penting terhadap proses penyimpanan ingatan jangka pendek, kemampuan belajar dan aktivitas kognitif kompleks, seperti memberikan atensi, belajar, bernalar, memahami bacaan, keterampilan matematika serta pencapaian prestasi belajar yang optimal, khususnya pada siswa kelas V Sekolah Dasar.

Alasan pemilihan kelas V Sekolah Dasar dikarenakan kurikulum dalam mata pelajaran kelas V lebih banyak menekankan pada proses berpikir kritis, bernalar (reasoning) dan pemahaman (comprehension), termasuk pada pelajaran berhitung dan bahasa (Kemendikbud, 2013). Selain itu, siswa kelas $\mathrm{V}$ juga telah menguasai dan mengenal keterampilan mendasar seperti membaca serta memiliki kelancaran dalam aspek berbahasa dibandingkan dengan kelas-kelas sebelumnya serta relatif lebih stabil dalam fluktuatif working memory (Dirk \& Schmiedek, 2016; Jared, Ashby, Agauas, \& Levy, 2016).

Tujuan penelitian adalah untuk menguji pengaruh permainan congklak terhadap kapasitas working memory pada siswa kelas V Sekolah Dasar. Manfaat penelitian adalah untuk mengembangkan kajian keilmuan psikologi kognitif dan mengenalkan kepada masyarakat mengenai keuntungan bermain congklak terhadap kapasitas kognitif dan proses belajar anak secara akademis. 


\section{Metode}

Subjek penelitian adalah 12 partisipan (5 laki-laki dan 7 perempuan) kelas V SD XX di Jakarta Barat yang memiliki rerata nilai pelajaran (Matematika, IPA, dan Bahasa) di bawah $\mathrm{KKM}$ kelas $(n=12$; rerata nilai $=$ 59,6). Mereka berusia berkisar 9-11 tahun $(M=10,24, S D=2,56)$ dan memiliki nilai yang rendah pada dua battery test working memory, yaitu digit span $(M=7,08)$ dan square span ( $M$ forward span $=4,67 \& M$ reverse span $=4,25)$. Artinya, 12 partisipan tersebut memiliki nilai prestasi belajar dan kapasitas working memory yang tergolong rendah dibandingkan dengan anak-anak lain seusianya di kelas V Sekolah Dasar.

Kriteria pemilihan subjek penelitian didasarkan dari keluhan guru, nilai rerata pelajaran kelas, dan skor dua battery test working memory yang diberikan peneliti. Dua belas siswa kelas $\mathrm{V}$ yang paling memenuhi kriteria akan menjadi subjek penelitian dan dibagi menjadi dua kelompok. Kelompok pertama merupakan kelompok perlakuan $(n=6$; 3 anak lakilaki \& 3 anak perempuan) dan kelompok kedua adalah kelompok kontrol $(n=6 ; 2$ anak laki-laki \& 4 anak perempuan). Metode penelitian yang dilakukan oleh peneliti adalah metode kuantifatif dengan eksperimen desain dua kelompok. Kedua kelompok dibagi secara acak sesuai dengan penyebaran interval rerata nilai pelajaran menjadi kelompok perlakuan dan kelompok kontrol. Peneliti mengambil data pre-test dan post-test pada kedua kelompok tersebut untuk menguji besarnya pengaruh pemberian perlakuan terhadap kelompok yang diberikan perlakuan permainan congklak.

Pengambilan data dilakukan di SD XX Jakarta Barat. Dua alat ukur kapasitas working memory adalah digit span dan square span forward/reverse. Alat ukur digit span subtes Wechsler Intelligence Scale for Children (WISC) mengukur kemampuan phonological loop dan alat ukur square span forward/reverse (Dede, Ricca, Knilans, \& Trubl, 2014) mengukur kemampuan visuospatial sketchpad. Dua battery test tersebut digunakan sebagai alat ukur prepost kapasitas working memory dua belas partisipan yang menjadi subjek penelitian. Perlengkapan intervensi yang digunakan adalah tiga papan permainan congklak lengkap dengan kecik serta ruangan audio-visual yang terdapat di dalam area perpustakaan SD XX.

Peneliti menanyakan guru-guru kelas V SD XX mengenai nilai rerata pelajaran Matematika, IPA dan Bahasa siswa yang berada di bawah KKM. Siswa yang dirujuk oleh guru kelas dilakukan pre-test dengan square span dan digit span. Dua belas subjek penelitian yang memenuhi kriteria penelitian dibagi menjadi dua kelompok yang dibagi secara acak dengan mengacu kepada kesetaraan usia dan interval rerata nilai pelajaran di dalam kelas. Kelompok perlakuan diberikan intervensi permainan congklak yang dilakukan selama 30 menit perhari, 3 kali seminggu dalam kurun waktu 3 minggu berturut-turut. Di akhir periode intervensi, peneliti mengambil kembali data post-test dari kedua kelompok. Pengolahan data menggunakan uji beda paired sample T-test dan independent sample T-test dengan SPSS for Windows versi 15.

\section{Hasil}

Uji normalitas kolmogorov-smirnov didapati bahwa penyebaran data normal pada keempat hasil pengukuran digit span $(Z=$ $1,155, p>0,05)$, square spanforward $(Z=$ $0,798, p>0,05)$, square span reverse $(Z=$ $0,733, p>0,05)$ dan rerata nilai pelajaran kelas $(Z=0,652, p>0,05)$ antara kelompok 
perlakuan dengan kelompok kontrol setelah menjalani proses intervensi permainan congklak. Hasil uji beda dengan independent sample T-test menunjukkan adanya perbedaan yang signifikan pada tingkat 0,05 dalam kemampuan menyebutkan kembali deret angka (digit span) yang dapat dilafalkan kembali oleh subjek penelitian, $t(10)=2,481, p<0,05$ dan kemampuan pemahaman ruang (jejak gambar) mengenai orientasi arah atas, bawah, kiri dan kanan secara visual ketika peneliti meminta mengulangi jejak arah dari bagian akhir ke awal (square span reverse), $t(10)=3,167, p<0,05$.

Di sisi lain, tidak terdapat perbedaan yang signifikan pada tingkat 0,05 dalam kemampuan pemahaman ruang (jejak gambar) mengenai orientasi arah atas, bawah, kiri dan kanan secara visual ketika peneliti meminta mengulangi jejak arah dari bagian awal ke akhir (square span forward $), t(10)=2,168, p>0,05$ dan kemampuan belajar pada pelajaran berhitung, mengingat dan memahami bacaan yang tergambar dari rerata nilai pelajaran Matematika, IPA dan Bahasa Indonesia di kelas, $t(10)=0,356, p>0,05$.

Uji normalitas kolmogorov-smirnov sebelum dan setelah pemberian intervensi permainan congklak pada kelompok perlakuan, didapati bahwa penyebaran data normal pada pre-testdigit span $(\mathrm{Z}=$ $0,782, p>0,05)$ dan post-testdigit span $(Z=$ $0,717, p>0,05)$; pre-testsquare span forward ( $Z$ $=0,753, p>0,05)$ dan post-test square span forward $(Z=0,688, p>0,05)$; pre-testsquare span reverse $(Z=0,615, p>0,05)$ dan post-test square span reverse $(Z=0,485, p>0,05)$; serta pre-test rerata nilai pelajaran $(Z=0,605$, $p>0,05)$ dan post-test rerata nilai pelajaran $(Z=0,475, p>0,05)$.

Hasil uji beda dengan paired samples $T$ test menunjukkan adanya perbedaan yang signifikan pada tingkat 0,05 dalam kemampuan menyebutkan kembali deret angka (digit span) pada saat sebelum dan sesudah mendapatkan intervensi permainan congklak di dalam kelompok perlakuan, $t(5)=-2,988, p<0,05$ dan kemampuan pemahaman keruangan (jejak gambar) mengenai arah atas, bawah, kiri dan bawah secara visual dalam urutan maju (square span forward), $t(5)=-3,968, p<0,05$. Bahkan, perbedaan yang signifikan pada tingkat 0,01 terjadi pada kemampuan pemahaman keruangan dalam urutan mundur (square span reverse) $t(5)=-6.528$, $p<0,01$. Tetapi, tidak ditemukan adanya perbedaan yang signifikan pada tingkat 0,05 dalam kemampuan belajar secara berhitung, mengingat dan memahami makna bacaan yang tergambarkan dari rerata nilai pelajaran Matematika, IPA dan Bahasa Indonesia di kelas, $t(5)=-1,871$, $p>0,05$.

Hasil analisis di atas menunjukkan bahwa pemberian intervensi permainan congklak mampu memengaruhi kapasitas working memory dalam bentuk mengingat dan menyebutkan kembali jumlah angka yang disebutkan secara berurutan. Lebih dari itu, permainan congklak juga mampu memengaruhi kapasitas working memory dalam mengingat jejak gambar, arah dan keruangan yang bersifat maju (forward) dan mundur (reverse) secara visual. Di sisi lain, permainan congklak tidak memberi pengaruh terhadap kapasitas working memory yang tergambar dalam kemampuan dan prestasi nilai belajar di dalam kelas.

Gambaran hasil penelitian sebelum dan sesudah pemberian intervensi permainan congklak terhadap 12 subjek penelitian dapat dilihat dari tabel 1 berikut ini. 
WORKING MEMORY, PERMAINAN CONGKLAK, SISWA SEKOLAH DASAR

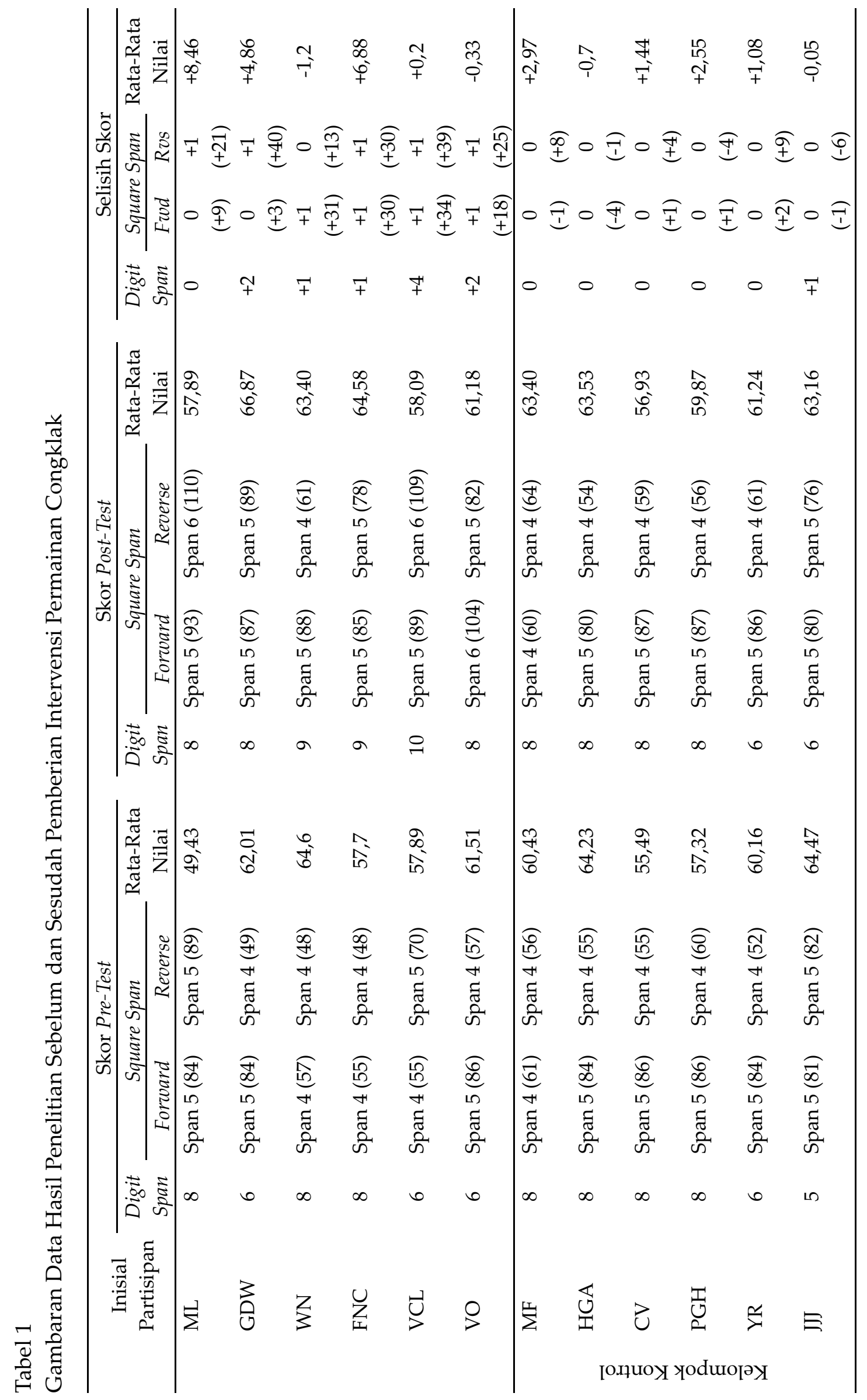




\section{Diskusi}

Hasil penelitian menunjukkan kesesuaian dengan teori Baddeley (2003) mengenai sistem aktif yang bekerja selama seseorang melakukan suatu tugas tertentu. Sistem aktif ini berkaitan dengan penyimpanan informasi sementara bersifat visual-spasial dalam visuospatial sketchpad dan bersifat verbal-bunyi dalam phonological loop. Ketika bermain congklak, anak memberikan perhatian (atensi) kepada pergerakan tangan dalam menjalankan kecik, menghitung kecik, mengingat posisi pengambilan kecik yang menguntungkan, merencanakan strategi dengan cara bermain yang menyenangkan serta memunculkan emosi positif.

Keseluruhan proses kognitif kompleks yang terjadi selama bermain congklak ini akan memberikan pelatihan yang bersifat terus-menerus (drilling) terhadap komponen-komponen dalam working memory yang dikemukakan oleh Baddeley (2003) dalam model multi komponen working memory (Klingberg, 2010; Thompson \& Holmes, 2008). Kemampuan berhitung jumlah kecik dalam komponen phonological loop dan kemampuan memberikan atensi, mengingat serta merencanakan pergerakan kecik dalam komponen visuospatial sketchpad adalah dua komponen yang terus aktif selama proses permainan congklak berlangsung. Permainan congklak menjadi media pelatihan menyenangkan yang secara tidak langsung meningkatkan kapasitas working memory, khususnya anak usia Sekolah Dasar (Baddeley, 2003; Fahimi et al., 2014; Hughes, 2010).

Hasil penelitian juga sejalan dengan studi De La Cru, Cage dan Lian yang dikutip oleh De Voogt (2010) serta studi Muslimin et al. (2012) yang menunjukkan bahwa kemampuan kognitif dan berhitung matematis meningkat dengan bermain congklak. Selain berhitung, congklak juga membantu anak dalam memberikan atensi, konsentrasi dan kemampuan motorik (Triyuda, Yuline, \& Ali, 2013). Penelitian ini juga senada dengan studi Donkers, De Voogt, dan Utterwijk (2000) yang menyatakan bahwa permainan congklak dapat melatih kemampuan strategi mengingat, seperti chunking dan visual-imagery. Latihan kemampuan strategi mengingat yang dilakukan secara terus-menerus selama proses bermain congklak merupakan salah satu hal terpenting juga yang memengaruhi proses penyimpanan informasi dalam kapasitas working memory siswa (Klingberg, 2010; Thompson \& Holmes, 2008).

Peningkatan kapasitas working memory tampak pada kenaikan skor battery test kapasitas working memory, namun tidak tergambar pada meningkatnya rata-rata nilai pelajaran di kelas. Hasil penelitian ini berbeda dengan studi Lee dan Bull (2016) mengenai korelasi peningkatan kapasitas working memory dengan hasil prestasi belajar siswa di dalam kelas. Perbedaan ini dikarenakan studi yang dilakukan Lee dan Bull (2016) merupakan penelitian bersifat longitudinal yang dilakukan dalam kurun waktu satu tahun. Selain itu, hasil prestasi belajar Matematika juga menggunakan alat ukur The Numerical Operation Task dari WIAT yang dilakukan secara terkondisi. Berbeda dengan itu, cara pengujian peneliti terhadap hasil belajar siswa diambil dari rerata tiga nilai pelajaran (Matematika, IPA dan BI) dalam lingkup ujian dan keseharian tugas di kelas.

Kondisi kelas yang berbeda dengan kondisi ruangan ketika pengambilan data terhadap dua battery test secara individual akan memengaruhi tingkat distraksi siswa dalam memberikan perhatian (atensi). Siswa akan lebih mudah memberikan 
atensinya pada lingkup pengambilan data individual dibandingkan kondisi di dalam kelas (Autin \& Croizet, 2012; Dirk \& Schmiedek, 2016). Faktor kondisi kesehatan fisik, waktu tidur, situasi kelas dan posisi tempat duduk yang kurang menguntungkan juga dapat menjadi faktor penyebab kurang maksimalnya siswa dalam menunjukkan prestasi belajar di dalam kelas (Dirk \& Schmiedek, 2016). Di samping itu, masalah kecemasan dan interpretasi kesulitan siswa terhadap pelajaran tertentu akan memengaruhi fluktuatif kapasitas working memory dalam bekerja secara optimal (Autin \& Croizet, 2012; Witt, 2012).

Hasil penelitian juga menunjukkan peningkatan skor square span pada kemampuan visuospatial sketchpad lebih tinggi dibandingkan dengan skor digit span pada komponen phonological loop. Hal ini disebabkan selama proses bermain congklak, siswa memberikan perhatian (atensi) yang bersifat terus-menerus terhadap pergerakan kecik dari permainan congklak, baik pada saat gilirannya maupun lawan mainnya. Peningkatan durasi waktu pemberian atensi siswa terhadap pergerakan kecik pada congklak berkaitan erat dengan peningkatan kapasitas penyimpanan informasi yang bersifat visual-spasial (Baddeley, 2003, Smedt et al., 2009). Dari segi sikap kerja, siswa dalam kelompok perlakuan menunjukkan kemampuan memberi perhatian (atensi) dan konsentrasi terhadap penjelasan guru yang lebih baik dibandingkan sebelum mendapat intervensi permainan congklak.

Subjek penelitian yang terbatas pada siswa kelas V Sekolah Dasar menjadikan hasil penelitian hanya terbatas pada jenjang pendidikan di kelas V Sekolah Dasar dan tidak pada jenjang pendidikan yang luas. Kesamaan lokasi sekolah subjek penelitian antara kelompok perlakuan dan kelompok kontrol juga menyebabkan data hasil penelitian yang diperoleh tidak dapat digeneralisasikan secara meluas oleh karena bias budaya sekolah. Kontrol terhadap subjek penelitian juga perlu memperhatikan faktor-faktor seperti pengenalan partisipan akan permainan congklak sebelumnya, urutan kelahiran di dalam keluarga, jenis kelamin, kondisi lingkungan rumah, kelas dan kesamaan lokasi penelitian antara partisipan kelompok perlakuan dan kelompok kontrol. Lebih dari itu, ketiadaan intereter/observer di luar peneliti dalam pelaksanaan intervensi juga sangat rentan dengan faktor subjektivitas dan bias.

\section{Kesimpulan}

Berdasarkan hasil penelitian yang telah dilakukan, dapat disimpulkan bahwa terdapat pengaruh dari permainan congklak terhadap kapasitas working memory pada siswa kelas V Sekolah Dasar. Pengaruh tersebut tampak pada meningkatnya dua kemampuan proses penyimpanan sementara secara visual (gambar) dalam komponen visuospatial sketchpad dan secara verbal (bunyi) dalam komponen phonological loop.

Lebih dari itu, permainan congklak menunjukkan pengaruh yang besar pada kemampuan pemahaman ruang (jejak gambar) berkenaan dengan orientasi arah atas, bawah, kanan dan kiri secara visual dibandingkan kemampuan menyimpan informasi secara verbal (bunyi). Namun di sisi lain, permainan congklak tidak memberi pengaruh terhadap hasil belajar siswa kelas V SD yang tergambar dari prestasi nilai rata-rata belajar pada ketiga pelajaran yang berkaitan dengan mengingat, berhitung dan memahami bacaan di dalam lingkup kelas. 
Saran

Sekolah dapat menggunakan media permainan congklak sebagai salah satu sarana pembelajaran di dalam kelas, khususnya Sekolah Dasar. Pengenalan permainan congklak pada anak usia Sekolah Dasar dapat meningkatkan kapasitas working memory siswa, khususnya dalam memberikan perhatian, berpikir, bernalar, mengingat, menetapkan strategi, merencanakan dan memecahkan masalah di kelas.

Selain itu, orang tua juga dapat menyediakan, mengenalkan dan mengajarkan permainan congklak dalam mengisi waktu luang anak di rumah. Guru dan pihak sekolah diharapkan dapat menjadi figur pembawa perubahan (agent of change) yang dapat mengimplikasikan permainan congklak dalam kurikulum/ proses pembelajaran di sekolah serta mampu mewariskan dan melestarikan permainan tradisional congklak yang ada di Indonesia.

\section{Kepustakaan}

Alloway, T. P.,\& Alloway, R. G. (2010). Investigating the predictive roles of working memory and IQ in academic attainment. Journal of Experimental Child Psychology, 106, 20-29. doi: 10.1016/j.jecp.2009.11.003

Andrews, S. C., Hoy, K. E., Enticott, P. G., Daskalakis, Z. J., \& Fitzgerald, P. B. (2011). Improving working memory: the effect of combining cognitive activity and anodal transcranial direct current stimulation to the left dorsolateral prefrontal cortex. Brain Stimulation, 4, 84-89. doi: 10.1016/ j.brs.2010.06.004

Arindiono, R., Y.,\& Ramadhani, N. (2013). Perancangan media pembelajaran interaktif matematika untuk siswa kelas 5 SD. Jurnal Sains dan Seni Pomits, 1(2), 1-5.

Autin, F.,\& Croizet, J. C. (2012). Improving working memory efficiency by reframing metacognitive interpretation of task difficulty. Journal of Experimental Psychology, 141(4), 610-618. doi: 10.1037/a0027478

Baddeley, A. (2000). The episodic buffer: A new component of working memory? Trends in Cognitive Science, 11(4), 417208.

Baddeley, A. (2003). Working memory and language: An overview. Journal of Communication Disorders, 36, 189-208. doi: 10.1016/S0021-9924(03)00019-4

Bailey, H., Dunlosky, J., \& Kane, M. J. (2008). Why does working memory span predict complex cognition? Testing the strategi affordance hypothesis. Memory E Cognition, 36(8), 1383-1390. doi: 10.3758/MC.36.8.1383

Cockcroft, K. (2015). The role of working memory in childhood education: Five questions and answers. South African Journal of Early Children Education, 5(1), 1-21.

Dede, G., Ricca, M., Knilans, J., \& Trubl, B. (2014). Construct validity and reliability of working memory tasks for people with aphasia. Aphasiology, 28(6), 692-712. doi: 10.1080/ 02687038. 2014.895973

De Voogt, A. (2010). Philippine Sungka and Cultural Contact in Southeast Asia. Asian Ethnology, 69(2), 333-342.

Dirk, J.,\& Schmiedek, F. (2016). Fluctuations in elementary school children's working memory performance in school context. Journal of Educational Psychology, 108(5), 722-739. doi: 10.1037/edu0000076

Donkers, J., De Voogt, A., \& Uiterwijk, J. (2000). Human versus machine 
problem solving: Winning openings in Dakon. Board Games Studies, 3, 79-88.

Fahimi, M., Arjmandnia, A. A., \& Fathabadi, J. (2014). Investigating efficacy of "working memory training software" on students working memory. Health, 6, 2236-2244. doi: 10.4236/health.2014.616259

Friend, M. (2011). Special education: Contemporary perspectives for school professionals (3rd ed.). New Jersey: Pearson Education, Inc.

Goldstein, J. (2012). Play in children's development, health and well-being. London, UK: Toy Industries of Europe.

Hughes, F. P. (2010). Children, play, and development (4th ed.). London, UK: SAGE Publications, Inc.

Jared, D., Ashby, J., Agauas, S. J., \& Levy, B. A. (2016). Phonological activation of word meanings in grade 5 readers. Journal of Experimental Psychology: Learning, Memory, and Cognition, 42(4), 524-541. doi: 10.1037/xlm0000184

Kemendikbud (2013). Kompetensi dasar Sekolah Dasar/Madrasah Ibtidaiyah. Jakarta. Diunduh dari: http://www.pendidikan-diy.go.id/ file/mendiknas/kurikulum-2013kompetensi-dasar-sd-ver-3-3-2013.pdf

Klingberg, T. (2010). Training and plasticity of working memory. Trends in Cognitive Sciences, 14, 317-324. doi: 10. 1016/j.tics.2010.05.002

Lee, K.,\& Bull, R. (2016). Developmental changes in working memory, updating, and math achievement. Journal of Educational Psychology, 108(6), 869-882. doi: 10.1037/ edu 0000090

Muslimin, Putri, R. I. I., \& Somakim (2012). Desain pembelajaran pengurangan bilangan bulat melalui permainan tradisional congklak berbasis pendidikan matematika realistik Indonesia di kelas IV Sekolah Dasar. Jurnal Kreano, 3(2), 100-112.

Putri, E. W. S., \& Sudianto, M. (2013). Penerapan metode mind map untuk meningkatkan kemampuan mengingat di sekolah dasar. JPGSD, 1(2), 111.

Santrock, J. W. (2011). Educational psychology (5thed.). New York: Mc.GrawHill.

Schunk, D. H.,\& Zimmerman, B. J. (2012). Motivation and self-regulated learning: Theory, research and applications. New York, NY: Routledge

Smedt, B. D., Janssen, R., Bouwens, K., Verschaffel, L., Boets, B., \& Ghesquiere, P. (2009). Working memory and individual differences in mathematics achievement: A longitudinal study from first grade to second grade. Journal of Experimental Child Psychology, 103, 186-201. doi: 10. 1016/j.jecp.2009.01.004

Thompson, H. C., \& Holmes, J. (2008). Improving short-term and working memory: Methods of memory training. Dalam Noah B. Johansen (Eds.), New research on short-term memory (hlm. 1-30). New York: Nova Science Publishers, Inc.

Triyuda, D., Yuline,\& Ali, M. (2013). Mengenalkan kemampuan berhitung melalui permainan tradisional congklak pada anak usia 5-6 tahun. Jurnal Pendidikan dan Pembelajaran. 2(7), 1-9.

Witt, M. (2012). The impact of mathematics anxiety on primary school children's working memory memory. Europe's Journal of Psychology, 8(2), 263-274. doi: 10.5964/ejop.v8i2.458 